\title{
$\mathrm{AgI}-\mathrm{Ag}_{2} \mathrm{Ch}-\mathrm{P}_{2} \mathrm{Ch}_{5}$ 系 $(\mathrm{Ch}=\mathrm{O}, \mathrm{S}, \mathrm{Se})$ 超イオン伝導 ガラスの作製と伝導機構
}

\author{
（1985 年 7 月 8 日 受 理)
}

南

努*・清 水 琭 己

$\mathrm{AgI}-\mathrm{Ag}_{2} \mathrm{Ch}-\mathrm{P}_{2} \mathrm{Ch}_{5}$ 系 $(\mathrm{Ch}=\mathrm{O}, \mathrm{S}, \mathrm{Se})$ 超イオン伝導ガラスを作製し, ガラス転移温度, イオン伝導 度, 電子伝導度, イオン輸率などを測定し，陰イオンを $\mathrm{O}, \mathrm{S}, \mathrm{Se}$ と変化させた影響を調べるととも に, 伝導機構を考察した。

ガラス生成域は硫化物系がもっとも広く, 酸化物系とセレン化物系とは大差がなかった。ガラス転移 温度は $50 \sim 230^{\circ} \mathrm{C}$ の範囲で変化し，構成成分の含量が同じガラスについて比較すると，酸化物系<硫 化物系くセレン化物系の順に高くなる傾向があった。またガラス転移温度の組成依存性から, $\mathrm{Ag}^{+}$1 オンの一部は, 非橋かけの陰イオンと強い部分的共有結合を形成していることが示された。伝導度は各 系とも室温で $10^{-2} \mathrm{~S} \cdot \mathrm{cm}^{-1}$ の值を示すものが得られた。イオン輸率の值から, ここで得られたガラス はすべて, ほぼ 100\% $\mathrm{Ag}^{+}$イイオン伝導体とみなすことができ, 電子伝導度は全伝導度より 5 〜 ケタ も低い値であった。伝導機構として, ランダムサイトモデル, 弱電解質モデル, 拡散路モデルについて 検討したところ，全体として，拡散路モデルがもっとも妥当であると結論した。

\section{1 楮言}

高いイオン伝導性を有する固体，すなわち固体電解質あるいは 超イオン伝導体に対する関心が非常に高まっている1”。半導体を はじめとして, 各種エレクトロニクス機器が固体素子化によって 信頼性が向上し, 小型, 軽量化が急速に進んだことは周知のとお りであるが，荷電担体が電子や正孔であるエレクトロニクス分野 にくらべて, イオンが主役を果たすイオニクス的と呼ばれる分野 は，まだ固体素子化が十分とはいい難い。イオニクス分野におけ る固体素子化の強い要望が，超イオン伝導体に対する関心を高め る大きな理由の一つと考えられる。

超イオン层導体といらと，通常結晶材料を指すことが多い。と ころが, 同じ化学組成の固体では, イオン伝導度はガラスの方が 結晶より一般に大きいので，Kunze ${ }^{21}$ による超イオン伝導ガラス の偶然の発見に端を発して，イオニクス分野ではガラスが注目さ れている゙。このよらなイオン伝尊性の高いガラスを, 結晶と区 別するために, “超イオン伀等がラス”といと表现がよく用いら れる。

超イオン伝導ガラスについては，これまでにすでにかなり多く の報告がありり、このようなガラスは，従来ガラス㭋造の特徽と されている三次元無規則網目たけでなく，むしろ低分子性のイオ

大阪府立大学工学部㐫用化学科，591 堺市百舌鳥梅町

1）高橋武应，応用物理，49，956(1980).

2) D. Kunze, "Fast Ion Transport in Solids", ed. W. van Gool, North Holland Pub., Amsterdam (1973) p. 405.

3) T. Minami, J. Non-Cryst. Solids, 56, 15(1983).

4) 南 努, 化学, 38, 412(1983).
ンがおもな構成単位となっている“イオンガラス”、呼ぶことの できるものが多いこと、100\% $\mathrm{Ag}^{+}$イオン伝導体であること, 結 晶にくらべてがラスの方がかなり高い伝導度を示すことなどが明 らかにされている(3) 6)

このようなガラスの組成は $\mathrm{AgI}-\mathrm{Ag}_{2} \mathrm{O}-\mathrm{M}_{x} \mathrm{O}_{y}\left(\mathrm{M}_{x} \mathrm{O}_{y}\right.$ は $\mathrm{B}_{2} \mathrm{O}_{3}, \mathrm{GeO}_{2}, \mathrm{MoO}_{3}$ など各種の酸化物) と表現できるものが多い が，ヨウ素を他の八ロゲンで置換したときの伝導度におよぼす影 響を調べることが，伝導機溝を考察するうえで有効な方法である

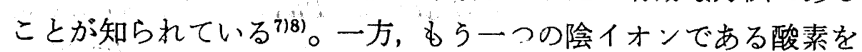
硫黄やセレンのような他の 6 族元素, いわゆるカルコゲン元絜(こ の論文では Ch と略記する）で置換して，その影響を調べること もまた興味ある方法と考えられる。さらに, 酸素を他の 6 族元素 で置換することは，伝尊度を向上させるのにも有効であるといわ

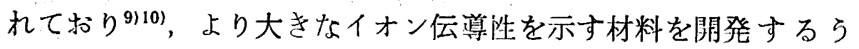
えでも期待がもたれる。

本論文では, $\mathrm{AgI}-\mathrm{Ag}_{2} \mathrm{Ch}-\mathrm{P}_{2} \mathrm{Ch}_{5}$ 系 $(\mathrm{Ch}=\mathrm{O}, \mathrm{S}, \mathrm{Se})$ のガラス

5) たとえば J. L. Souquet, Solid State Ionics, 5, 77 (1981); C. A. Angell, ibid., 9/10, 3(1983); 南㚵, 表面，23，92(1985)や，これらの中の引用文献参照.

6) T. Minami, K. Imazawa, M. Tanaka, J. Non-Cryst. Solids, 42, 469(1980).

7) T. Minami, M. Tanaka, Rev. Chim. Miner., 16, 283 (1979).

8) T. Minami, T. Shimizu, M. Tanaka, Solid State Ionics, 9/10, 597(1983).

9) J. L. Souquet, E. Robinel, ibid., 3/4, 317(1981).

10) E. Robinel, B. Carette, M. Ribes, J. Non-Cryst. Solids, 57, 49(1983). 
生成城をまず明らかにし，得られたガラス転移温度，伝導度，イ オン輸率などの結果を示し，伝導機構について考察する。なおこ れらのガラスのうち, $\mathrm{AgI}-\mathrm{Ag}_{2} \mathrm{O}-\mathrm{P}_{2} \mathrm{O}_{5}$ 系についてはすでに報告 したが11)，ここではそれらの結果も引用しつつ， $\mathrm{AgI}-\mathrm{Ag}_{2} \mathrm{Ch}-$ $\mathrm{P}_{2} \mathrm{Ch}_{5}$ 禾として，まとめて報告する。

\section{2 実験}

\section{1 ガラス試料の作製}

ガラス作製用原料としては, $\mathrm{AgI}-\mathrm{Ag}_{2} \mathrm{O}-\mathrm{P}_{2} \mathrm{O}_{5}$ 系の場合 $\mathrm{AgI}$, $\mathrm{Ag}_{2} \mathrm{O}, \mathrm{H}_{8} \mathrm{PO}_{4}$ を, $\mathrm{AgI}-\mathrm{Ag}_{2} \mathrm{~S}-\mathrm{P}_{2} \mathrm{~S}_{5}$ 系の場合 $\mathrm{AgI}, \mathrm{Ag}_{2} \mathrm{~S}, \mathrm{P}_{2} \mathrm{~S}_{5}$ を, $\mathrm{AgI}-\mathrm{Ag}_{2} \mathrm{Se}-\mathrm{P}_{2} \mathrm{Se}_{5}$ 系の場合 $\mathrm{AgI}, \mathrm{Ag}, \mathrm{P}, \mathrm{Se}$ をそれぞれ用 いた。これらの原料のらち, $\mathrm{AgI}$ は特級試薬の $\mathrm{KI}$ と $\mathrm{AgNO}_{3}$ と から湿式法によって合成したもの, $\mathrm{Ag}_{2} \mathrm{O}$ は特級試薬, $\mathrm{Ag}_{2} \mathrm{~S}$ は試 薬級， $\mathrm{P}_{2} \mathrm{~S}_{5}$ は一級試薬，Pは一級試薬の赤リン, $\mathrm{Ag}$ は純度 $99 \%$ 以上の粉末, Se は $99.999 \%$ の粒状試薬をそれぞれ用いた。リン 酸塩ガラスに扣ける $\mathrm{P}_{2} \mathrm{O}_{5}$ 成分の原料としては正りン酸やアンモ ニウム塩などが用いられるが，還元性雾囲気になるのを避けるた めに，ここでは正りン酸を用いた。また硫化物系とセレン化物系 においては，元素単体を原料として用いることがよく行なわれる がここれらの系のガラスは下記に述べるような封管反応で作製す るさい，爆発するおそれのあることがよく知られているので，入 手可能なかぎり化合物を出発原料とした。

これらの原料を総量が $5 \mathrm{~g}$ になるように所定量混合し, 内径 10 $\mathrm{mm}$ の石英ガラス管を反応容器として溶融反応させた。 $\mathrm{AgI}-\mathrm{Ag}_{2}$. $\mathrm{O}-\mathrm{P}_{2} \mathrm{O}_{5}$ 系の場合, このような反応容器の一端のみを封じた試験管 状の形状で用い, $500^{\circ} \mathrm{C}$ で数時間溶融後, 融液をステンレススチ ール板状に流しだしてガラスを得た。その他の系の場合，酸化を 防ぐために，原料を石英がラス管中に真空封入し，組成に応じて $650 \sim 1000^{\circ} \mathrm{C}$ で数時間 10 数時間溶融反応後, 真空封入した容 器ごと，氷水中に投入して急冷し，ガラスを得た。なお，この論 文で以下に述べるガラス組成は分析組成ではなく，バッチ組成で ある。酸化物系に拈いて，バッチ組成とガラス組成との間にずれ の生じるおちそれがあるが，二，三の代表的な組成のガラスにおい て，別の原料を用いて真空封入管で作製した試料との特性の比較 榆討により，差異のないことが確められている11。

得られた試料がガラスであるか不かの確認は，肉眼による観 察，粉末 X線回折法，および示差熱分析（DTA）で行なった。な

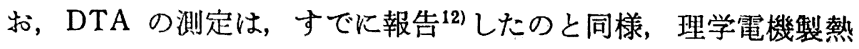
分析装置を用いて, 窒素がス流量 $70 \mathrm{~m} l / \mathrm{min}$, 昇温速度 $10^{\circ} \mathrm{C} / \mathrm{min}$ の条件で行ない，DTA 曲線からガラス転移温度 $T_{\mathrm{g}}$ を決定した。

\section{2 電気伝導度, イオン輸率および電子輸率の測定}

電気伝導度は, 乾燥窒素ガスを封入した黄銅製容器中で, ヒュ ーレットパッカード社製ベクトルインピーダンスメーター 4800 A 型で測定し, 複素インピーダンスプロットより求めた。測定試 料は平行平面に研磨し，その両面に $\mathrm{Au}$ を真空蒸着して電極とし た。

イオン輸率は，すでに既報年で詳しく述べたとおり，

$$
(-) \mathrm{Ag} / \text { ガラス試料 } / \mathrm{I}_{2}, \mathrm{C}(+)
$$

11) T. Minami, Y. Takuma, M. Tanaka, J. Electrochem. Soc., 124, 1659(1977).

12）南努, 池田裕司郎, 田中雅美, 日化, 1981, 1617.
の型の電池を組み，その開放端電圧（O. C. V.）を測定して,

$$
\mathrm{Ag}+\frac{1}{2} \mathrm{I}_{2}=\mathrm{AgI}
$$

の反応の標準起電力 $\left(=686.7 \mathrm{mV}, 25^{\circ} \mathrm{C}\right)$ との比から求める起電 力法补によった。

をた，電子輸率の測定も，既報 ${ }^{22)}$ で述べたとおり，

$$
\text { (一) } \mathrm{Ag} / \text { ガラス試料/ } \mathrm{Pt}(+)
$$

のように，一方を可逆電極，他方をブロッキンク電極として，直 流電圧を印加したときの電流一電圧特性から求める Wagner の分 極法 ${ }^{14}$ によった。

ガラス中の $\mathrm{Ag}^{+}$イオン濃度は, 比重を測定することによって 分子容を求め, 式量中の $\mathrm{Ag}$ のモル数を考慮して算出した。

\section{3 結果と考察}

\section{1 ガラス生成域}

図 1 に, $\mathrm{AgI}-\mathrm{Ag}_{2} \mathrm{Ch}-\mathrm{P}_{2} \mathrm{Ch}_{5}$ 系 $(\mathrm{Ch}=\mathrm{O}, \mathrm{S}, \mathrm{Se})$ のガラス生成 域を示す。図中，○印はガラス， $\triangle$ 印はわずかに結晶成分を含む もの，×印は結晶であったことを意味する。得られたガラスの色 調は, $\mathrm{Ch}=\mathrm{O}$ の場合に透明淡黄色, $\mathrm{Ch}=\mathrm{S}$ の場合に透明橙色, $\mathrm{Ch}=\mathrm{Se}$ の場合に黒色であった。

ガラス形成能としては， $\mathrm{Cl}=\mathrm{O}$ より $\mathrm{S}$ や $\mathrm{Se}$ ことに $\mathrm{S} か ゙$ 優れ ていることがわかる。電子伝導性のカルコゲニドガラスにおい て，硫化物系がもっともガラス化しやすいこと融と合わせて，酸 化物系だけでなく, 非酸化物系も含めて，ガラス形成能を体系化 する上で一つの参考になることが期待できる。

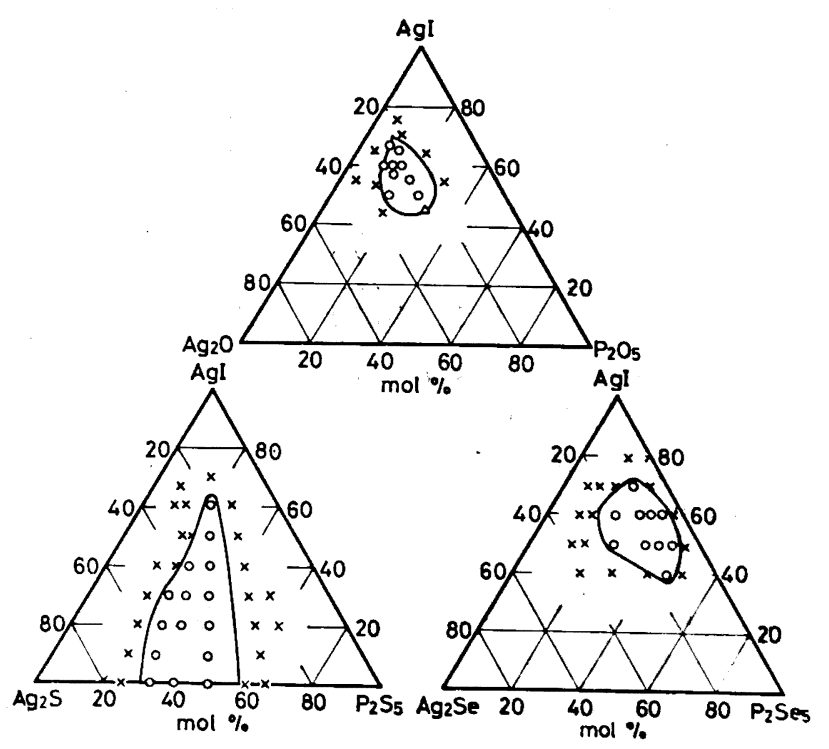

Fig. 1 Glass-forming regions in the systems AgI$\mathrm{Ag}_{2} \mathrm{Ch}-\mathrm{P}_{2} \mathrm{Ch}_{5}(\mathrm{Ch}=\mathrm{O}, \mathrm{S}, \mathrm{Se})$

The results for $\mathrm{Ch}=\mathrm{O}$ are cited from Ref. 11. $O$ : Glassy, $\triangle:$ Partially crystalline, $X:$ Crystalline

13) T. Takahashi, S. Ikeda, O. Yamamoto, J. Electro. chem. Soc., 120, 647(1973).

14) C. Wagner, Proc. C.I.T.C.E., VII, 361(1955).

15) A. R. Hilton, C.E. Jones, M. Brau, Phys. Chem. Glasses, 7, 105(1966). 
il오오오 This work

(a)

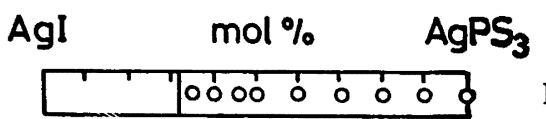

Ref. 16

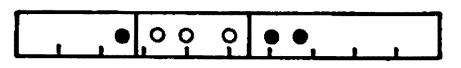

This work

(b)

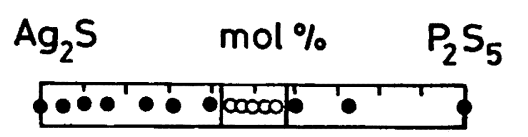

Ref. 17

Fig. 2 Comparison of the present glass-forming regions with those in references

(a): The pseudobinary systems $\mathrm{AgI}-\mathrm{AgPS}_{3}$

(b) : The binary system $\mathrm{Ag}_{2} \mathrm{~S}-\mathrm{P}_{2} \mathrm{~S}_{5}$

$\bigcirc$ : Glassy, $O$ : Crystalline

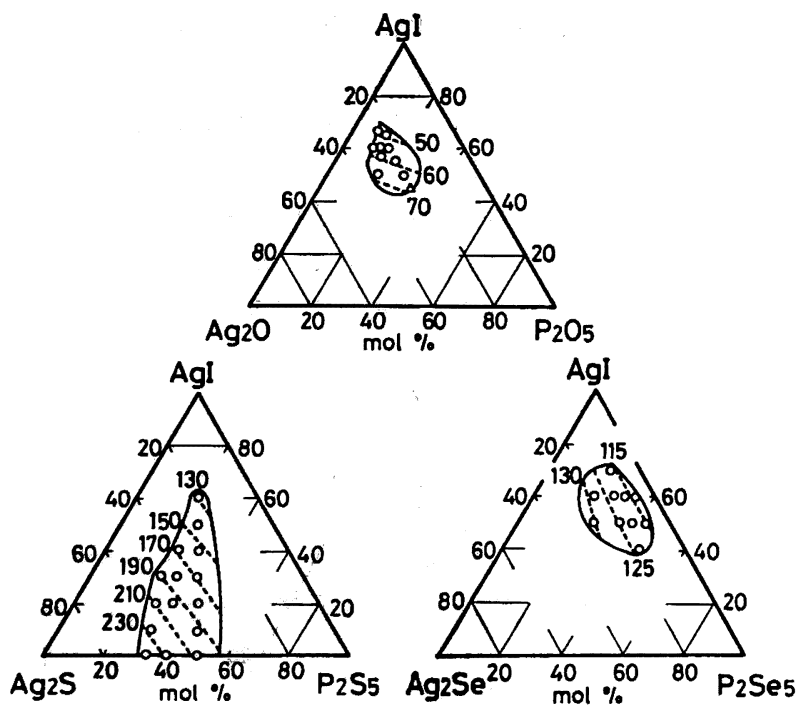

Fig. 3 Iso- $T_{\mathrm{g}}$ curves of glasses in the systems $\mathrm{AgI}-\mathrm{Ag}_{2} \mathrm{Ch}-\mathrm{P}_{2} \mathrm{Ch}_{5}(\mathrm{Ch}=\mathrm{O}, \mathrm{S}, \mathrm{Se})$

The numerals in the composition triangles are $T_{\mathrm{g}}$ in ${ }^{\circ} \mathrm{C}$.

なお,・ $\mathrm{AgI}-\mathrm{Ag}_{2} \mathrm{~S}-\mathrm{P}_{2} \mathrm{~S}_{5}$ 系に拈いて, $\mathrm{Ag}_{2} \mathrm{~S} / \mathrm{P}_{2} \mathrm{~S}_{5}$ のモル比が 1 の $\mathrm{AgI}-\mathrm{AgPS}_{3}$ 擬二成分系 ${ }^{16)}$ と, $\mathrm{AgI}$ を含まない $\mathrm{Ag}_{2} \mathrm{~S}_{-} \mathrm{P}_{2} \mathrm{~S}_{5}$ 系 ${ }^{171}$ にいては，すでに報告があるので，それらとの比較を図 2 に示す。四から， $\mathrm{AgI}-\mathrm{AgPS}_{3}$ 系は従来報告されているガラス生 成域とよく一致していることがわかる。一方, $\mathrm{Ag}_{2} \mathrm{~S}-\mathrm{P}_{2} \mathrm{~S}_{5}$ 系では 今回の結果の方がやや広くなっているが，冷却速度に少し差異が あるためであろらと考えられる。

\section{2 ガラス転移温度}

凶 $3 \mathrm{~K}, \mathrm{AgI}-\mathrm{Ag}_{2} \mathrm{Ch}-\mathrm{P}_{2} \mathrm{Ch}_{5}$ 系 $(\mathrm{Ch}=\mathrm{O}, \mathrm{S}, \mathrm{Se})$ ガラスのガラ

16) J. P. Malugani, G. Robert, R. Mercier, Mat. Res. Bull., 15, 715(1980).

17) Y.Kawamoto, M. Nishida, J. Non-Cryst. Solids, 20, 393(1976).
伡移温度 $\left(T_{\mathrm{g}}\right)$ の等高線を示す。三つの系でガラス生成域に重 なり部分が少ないので，直接の比較は困難であるが，同じ $\mathrm{AgI}$, $\mathrm{Ag}_{2} \mathrm{Ch}, \mathrm{P}_{2} \mathrm{Ch}_{5}$ 含量の場合, $T_{\mathrm{g}}$ は酸化物系<硫化物系くセレン 化物系の順に高くなる傾向がある。さらに， $T_{\mathrm{g}}$ の等高線はいず れの系においてもほぼ直線的な変化をしているが，その傾きが酸 化物系では水平 $\left(\mathrm{Ag}_{2} \mathrm{O}\right.$ と $\mathrm{P}_{2} \mathrm{O}_{5}$ を結ぶ線に平行 $)$ に近く, 硫化 物系ではかなり立ち上がった形 ( $\mathrm{AgI}$ と $\mathrm{P}_{2} \mathrm{~S}_{5}$ を結ぶ線に平行に 近く）になり，七レン化物系では $\mathrm{AgI}$ と $\mathrm{P}_{2} \mathrm{Se}_{5}$ を結ぶ線とほと んど平行になっていることは注目に值する。

たと学ば,酸化物系のように, $\mathrm{Ag}_{2} \mathrm{O}$ と $\mathrm{P}_{2} \mathrm{O}_{5}$ を結ぶ線に平行に なっていることは， $T_{\mathrm{g}}$ が $\mathrm{AgI}$ 含量によってほぼ決定されている ことになり，またセレン化物系のように, $\mathrm{AgI}$ と $\mathrm{P}_{2} \mathrm{Se}_{5}$ を結ぶ線 に平行になっていることは, $T_{\mathrm{g}}$ が $\mathrm{Ag}_{2} \mathrm{Se}$ 含量によって一義的に 支配されていることを意味する。

一般の酸化物ガラスでは， $\mathrm{Ag}_{2} \mathrm{O}$ のよ.うないわゆる網目修飾酸 化物が導入されると, 網目が切断されて $T_{\mathrm{g}}$ は減少することがよ く知られている。ところが，ここで示されているガラスでは， $\mathrm{AgI}$ の導入はほぼつねに $T_{\mathrm{g}}$ を低下させているものの, $\mathrm{Ag}_{2} \mathrm{Ch}$ の導入は $T_{\mathrm{g}}$ を減少させず，むしろ增大させる効果があり，しか も酸化物系く硫化物系くセレン化物系の順に, その効果の大きく なっていることがわかる。このことは, $\mathrm{Ag}_{2} \mathrm{Ch}$ の導入によって, いわゆる非橋かけの $\mathrm{Ch}^{-}$イオンが形成されて $T_{\mathrm{g}}$ を减少させる のではなく，むしろそのような $\mathrm{Ch}^{-}$と $\mathrm{Ag}^{+}$との間で，かなり強 い部分的共有結合が形成され，見かけ上，重合度が増大したよう な効果をもたらし， $T_{\mathrm{g}}$ を増大させたものと解釈することができ る。

$\mathrm{Ag}^{+}$イオンと, いわゆる非橋かけの酸素イオンとの間のこのよ らな共有結合的相互作用は, すでに $\mathrm{AgI}-\mathrm{Ag}_{2} \mathrm{O}-\mathrm{MoO}_{3}$ 系 ${ }^{18)}, \mathrm{AgI}$ $\mathrm{Ag}_{2} \mathrm{O}-\mathrm{B}_{2} \mathrm{O}_{3}$ 系 $^{8) 19)}$, さらにはここでもとりあげた $\mathrm{AgI}-\mathrm{Ag}_{2} \mathrm{O}-$ $\mathrm{P}_{2} \mathrm{O}_{5}$ 系20)のガラスなどについて，イオン交換にともなら赤外吸 収帯のピークシフトの実験で明らかにされているが, 今回 $T_{\mathrm{g}}$ の 組成依存性からも, このような共有結合的相互作用の存在が確認 されたことになる。

ことに，酸化物系く硫化物系くセレン化物系の順に，その相互 作用が強くなっていることは, Pearson のいわゆる “軟かい酸” である $\mathrm{Ag}^{+}$が, 酸化物, 硫化物, セレン化物の順に分極されやす く,より軟かい塩基との間で相互作用が強くなっていることを明 瞭に示していて興味深い。

\section{3 伝 導 度}

伝導度は複素インピーダンスプロットから求めたが，その測定 結果の一例を図 4 亿示す。試料組成は $60 \mathrm{AgI} \cdot 10 \mathrm{Ag}_{2} \mathrm{Se} \cdot 30 \mathrm{P}_{2} \mathrm{Se}_{5}$ (mol\%) であり，図中には測定温度と周波数を記入した。このよ らな複素インピーダンスプロットに打ける実軸（横軸）との交点 として抵抗を求め, 試料の厚さと電極面積から伝導度を算出し た。

伝導度の温度依存性を $\mathrm{AgI}-\mathrm{Ag}_{2} \mathrm{~S}-\mathrm{P}_{2} \mathrm{~S}_{5}$ 系ガラスを例として困 5 に示す。測定点の各記号は, 插入三角図の各試料組成に対応し

18) T. Minami, T. Katsuda, M. Tanaka, J. Non-Cryst. Solids, 29, 389(1978).

19) T. Minami, Y. Ikeda, M. Tanaka, ibid., 52, 159(1982).

20) T. Minami, T. Katsuda, M. Tanaka, J. Phys. Chem., 83, 1306(1979). 


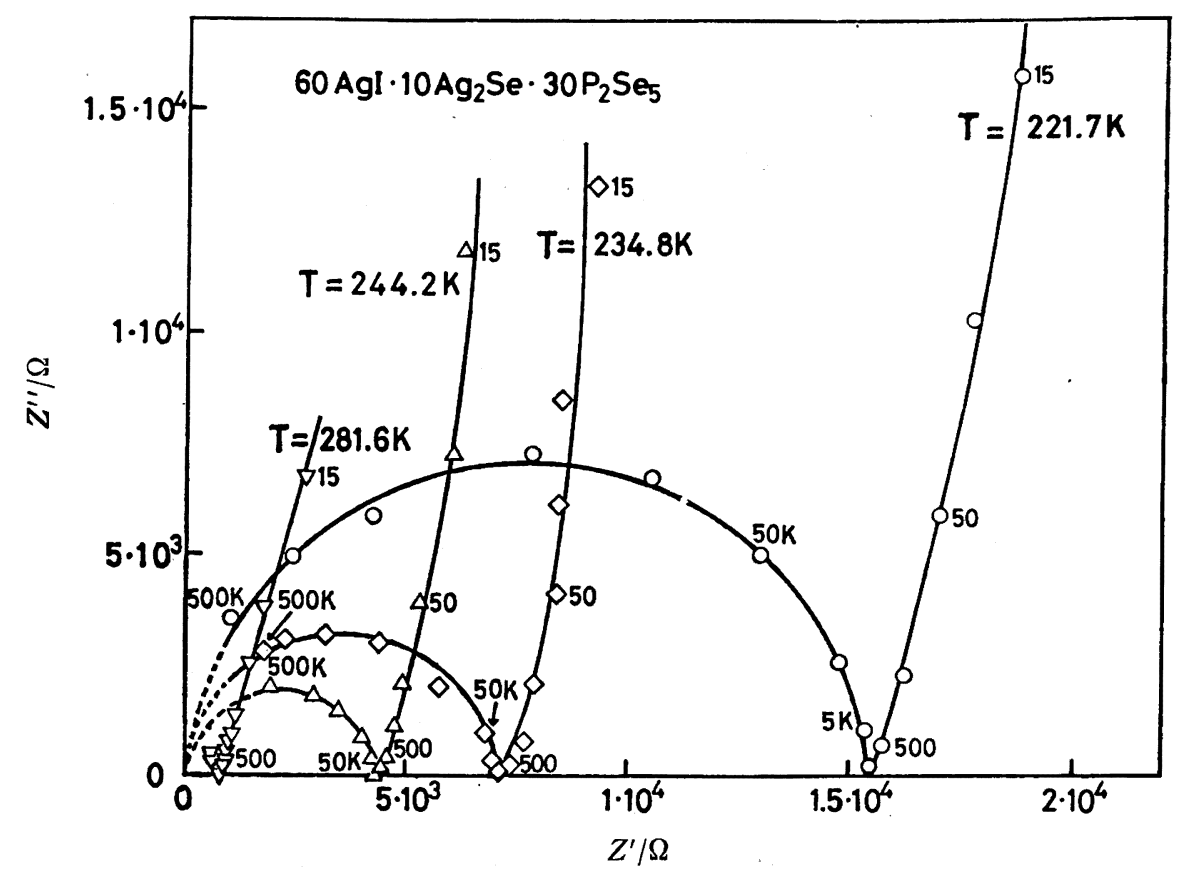

Fig. 4 Complex impedance plots for the determination of conductivities at various temperatures The sample composition is $60 \mathrm{AgI} \cdot 10 \mathrm{Ag}_{2} \mathrm{Se} \cdot 30 \mathrm{P}_{2} \mathrm{Se}_{5}(\mathrm{~mol} \%)$.

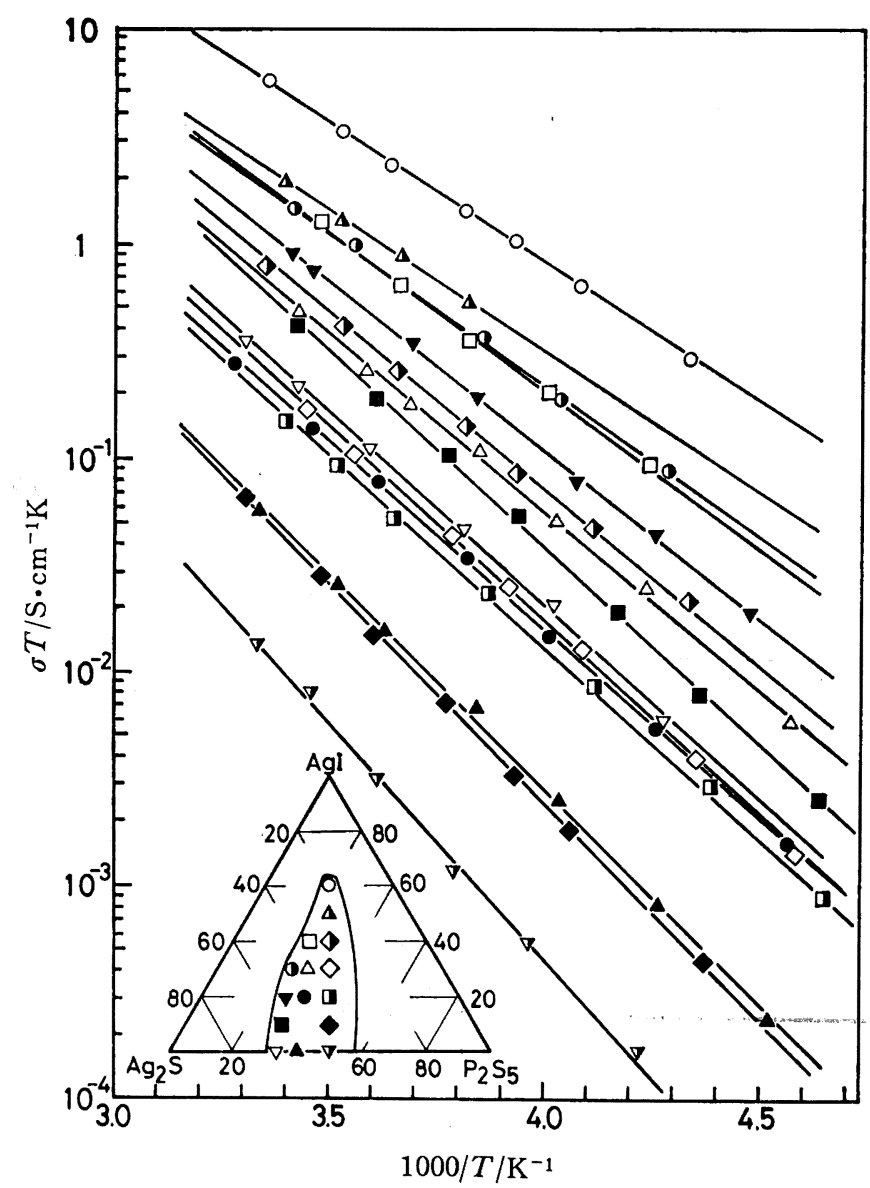

Fig. 5 Temperature dependence of conductivities in the $\mathrm{AgI}-\mathrm{Ag}_{2} \mathrm{~S}-\mathrm{P}_{2} \mathrm{~S}_{5}$ glasses

The symbols in the conductivity plots correspond to those in the composition triangle in. serted.
ている。伝導度 $\sigma$ と絶対温度 $T$ との積 $\sigma T$ が絶対温度の逆数に 対して指数関数的に変化して扣り,

$$
\sigma=\frac{\sigma_{0}}{T} \exp \left(-\frac{E}{R T}\right)
$$

の関係式を満足している。ここで $E$ は伝導の活性化ェネルギ一, $R$ は気体定数， $\sigma_{0}$ は定数である。 $E$ の値は $\mathrm{AgI}-\mathrm{Ag}_{2} \mathrm{O}-\mathrm{P}_{2} \mathrm{O}_{5}$ 系 では $5 \sim 7 \mathrm{kcal} / \mathrm{mol}, \mathrm{AgI}-\mathrm{Ag}_{2} \mathrm{~S}_{-}-\mathrm{P}_{2} \mathrm{~S}_{5}$ 系では $6 \sim 10 \mathrm{kcal} / \mathrm{mol}$, $\mathrm{AgI}-\mathrm{Ag}_{2} \mathrm{Se}-\mathrm{P}_{2} \mathrm{Se}_{5}$ 系では $6 \sim 8 \mathrm{kcal} / \mathrm{mol}$ であり, 非常に小さいの が特徵である。また $\sigma_{0}$ はほとんど $10^{5} \mathrm{~S} \cdot \mathrm{cm}^{-1} \cdot \mathrm{K}$ のオーダーで,

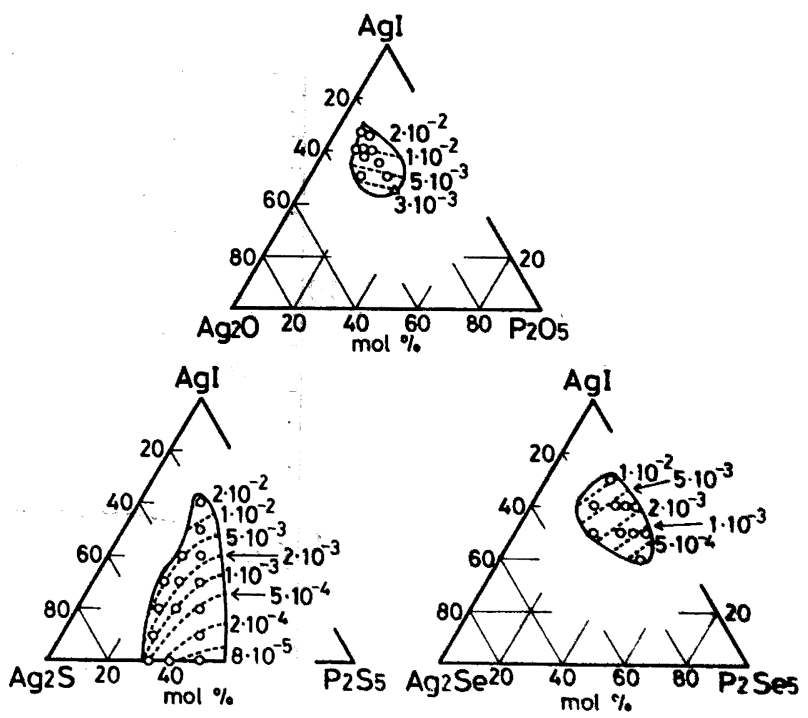

Fig. 6 Iso-conductivity curves of glasses in the systems $\mathrm{AgI}-\mathrm{Ag}_{2} \mathrm{Ch}-\mathrm{P}_{2} \mathrm{Ch}_{5}(\mathrm{Ch}=\mathrm{O}, \mathrm{S}, \mathrm{Se})$

The numerals in the composition triangles are the conductivities at $25^{\circ} \mathrm{C}$. 
Table 1 Electrolytic properties of $\mathrm{AgI}-\mathrm{Ag}_{2} \mathrm{Ch}-\mathrm{P}_{2} \mathrm{Ch}_{5}$ glasses $(\mathrm{Ch}=\mathrm{O}, \mathrm{S}, \mathrm{Se})$

\begin{tabular}{lllcc}
$\begin{array}{c}\text { Composition } \\
(\mathrm{mol} \%)\end{array}$ & $\begin{array}{c}\sigma_{\mathrm{t}_{\mathrm{t}}}{ }^{a)} \\
\left(\mathrm{S} \cdot \mathrm{cm}^{-1}\right)\end{array}$ & $\begin{array}{c}\sigma_{\theta^{b}} \\
\left(\mathrm{~S} \cdot \mathrm{cm}^{-1}\right)\end{array}$ & $\begin{array}{c}\text { O. C. V. } \\
(\mathrm{mV})\end{array}$ & $t_{\left.\mathrm{Ag}^{+}{ }^{d}\right)}$ \\
\hline $67 \mathrm{AgI} \cdot 25 \mathrm{Ag}_{2} \mathrm{O} \cdot 8 \mathrm{P}_{2} \mathrm{O}_{5}$ & $1.2 \times 10^{-2}$ & $4.7 \times 10^{-8}$ & 685.4 & $0.998_{1}$ \\
$40 \mathrm{AgI} \cdot 30 \mathrm{Ag}_{2} \mathrm{~S} \cdot 30 \mathrm{P}_{2} \mathrm{~S}_{5}$ & $2.6 \times 10^{-3}$ & $2.2 \times 10^{-8}$ & 677.7 & $0.986_{8}$ \\
$50 \mathrm{AgI} \cdot 25 \mathrm{Ag}_{2} \mathrm{Se} \cdot 25 \mathrm{P}_{2} \mathrm{Se}_{5}$ & $2.3 \times 10^{-8}$ & $8.4 \times 10^{-8}$ & 653.7 & $0.951_{9}$
\end{tabular}

a) Total conductivity at $25^{\circ} \mathrm{C}$.

b) Electron conductivity at $25^{\circ} \mathrm{C}$.

c) Open circuit voltage of the cell(1).

d) Transport number of $\mathrm{Ag}^{+}$ions.

ガラス組成の相違による変化は小さく，組成による层導度の変化 は活性化エネルギーの変化に支配されているといえる。

このような伝導度の温度依存性から求めた $25^{\circ} \mathrm{C}$ に打ける伝導 度 $\sigma_{25}$ の等高線を図 6 亿示す。いずれの系も $10^{-2} \mathrm{~S} \cdot \mathrm{cm}^{-1}$ におよ ぶ非常に高い伝導度を示していることがわかる。硫化物系におい て，等高線に湾曲が見られるものの，酸化物系とセレン化物系で は直線的であり，全般的に伝導度の値は AgI 含量によってほぼ 支配されていることがわかる。この問題については 3.5 節でさ らに検討する。

\section{4 イオン輸率, 電子輸率}

表 1 K, 各系から一つずつ代表例を選んで，それらの全伝導度 $\sigma_{\mathrm{t}}$ と $\mathrm{Ag}^{+}$イオン輸率 $t_{\mathrm{Ag}^{+}}$を示す。な扰表中には,つぎに述べ る Wagner の分極法 ${ }^{14}$ によって求めた電子の伝導度 $\sigma_{\theta}$ も示し てある。

イオン輸率はこの表に示したものだけでなく，ガラスが得られ た全試料について起電力法で求め, $0.95 \sim 1.0$ といら值が得られ た。

このよらなイオン伀導体に护けるわずかの電子伝導度を Wagner の分極法 ${ }^{14)}$ によって求めた結果を図 7 に示す。Wagner の分 極法によれば，（3）式に示したようなセルに電代を印加すると， 初期にはイオン電流も流れるが, 一方がブロッキング電極となっ ているので，定常状態では電子電流だけが流れ，そのときの全電 流 $I$ は

$$
\begin{aligned}
I= & I_{\mathrm{e}}+I_{\mathrm{h}}=\frac{R T A}{F L}\left\{\sigma_{\mathrm{e}}\left[1-\exp \left(-\frac{E F}{R T}\right)\right]\right. \\
& \left.+\sigma_{\mathrm{h}}\left[\exp \left(\frac{E F}{R T}\right)-1\right]\right\}
\end{aligned}
$$

で与えられる。ここで $I_{\mathrm{e}}$ と $I_{\mathrm{h}}$ はとれぞれ電子と正孔による電 流， $\sigma_{\mathrm{\theta}}$ と $\sigma_{\mathrm{h}}$ は電子と正孔炕子る伝導度， $E$ は印加電圧， $F$ は Faraday 定数, $A$ は試料の断面積, $L$ は陚料の厚さである。 $\sigma_{0}$ $\gg \sigma_{\mathrm{h}}$ のときは，(5)式に淤ける\{\}内内第 2 項は無視できて 第1項のみとなり，Iは $E$ 汪とんど依存しなくなる。また $\sigma_{\theta}$ 《 $\sigma_{\mathrm{h}}$ のときは，逆海 2 項のみとなり，Iは $E$ に対して指数関 数的に增加することになる。

図 7 の結果は，いずれのガラスも $\sigma_{\mathrm{\theta}} \gg \sigma_{\mathrm{h}}$ の条件が成立してい ることを示している。表 1 亿示した $\sigma_{\theta}$ は, この(5)式を適用し て求めたものである。全伝導度に対して, 電子伝導度は 5〜7 ケ 夕低い値になっており, 全伝導度に対する電子伝導度の寄与は注 とんど無視することができ，注ぼ $100 \%$ イオン伝導体と見なすこ とができる。

\section{5 伝導機構}

電気伝導度 $\sigma$ は一般に,

$$
\sigma=n e \mu
$$

で表わされる。ここで $n$ は荷電担体の濃度, $e$ は電荷, $\mu$ は移動 度である。因6で見られるよらに，ガラスの組成が変化すると伝

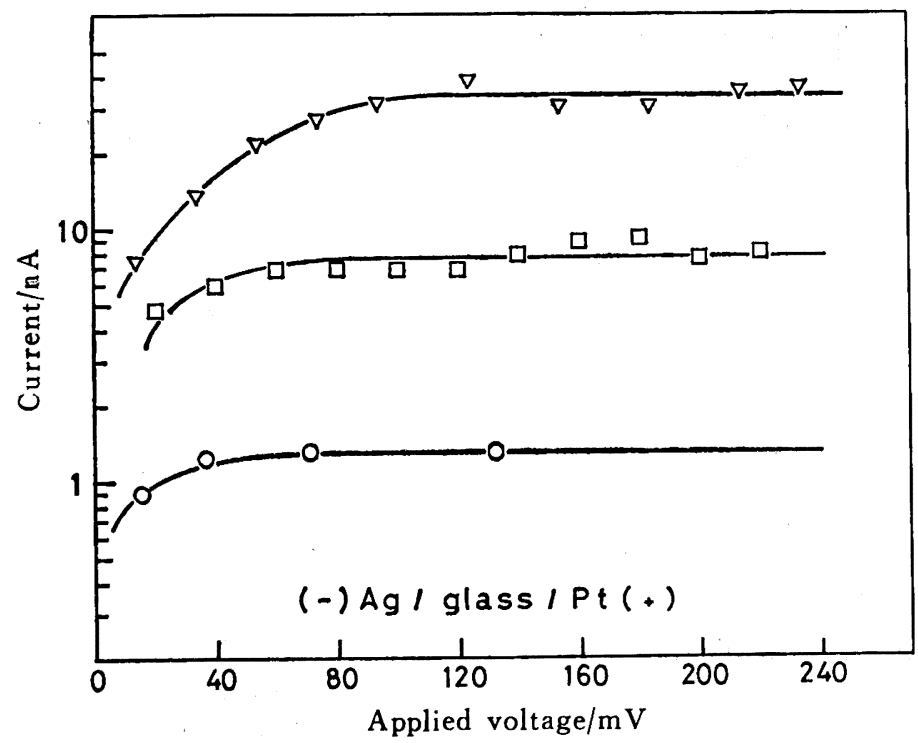

Fig. 7 Current-voltage characteristics at $25^{\circ} \mathrm{C}$ in the Wagner polarization cell of the type $(-) \mathrm{Ag} / \mathrm{glass} / \mathrm{Pt}(+)$ : $67 \mathrm{AgI} \cdot 25 \mathrm{Ag}_{2} \mathrm{O} \cdot 8 \mathrm{P}_{2} \mathrm{O}_{5}, \square: 40 \mathrm{AgI} \cdot 30 \mathrm{Ag}_{2} \mathrm{~S} \cdot 30 \mathrm{P}_{2} \mathrm{~S}_{5}, \nabla: 50 \mathrm{AgI} \cdot 25 \mathrm{Ag}_{2} \mathrm{Se} \cdot 25 \mathrm{P}_{2} \mathrm{Se}_{5}(\mathrm{~mol} \%)$ 
導度は大きく変化する（図は割愛するが，ある組成の系列につい て伝導度の変化を見ると，ほとんどつねに，組成の変化に対して 伝導度は指数関数的に変化する)。ガラス組成の変化に対するこ のよらな伝導度の変化を説明するために, これまでに, 以下に示 すような三つの説が提案されている。

（1）組成が変化したとき， $n$ はほとんど変化せず， $\mu$ の変化が $\sigma$ の変化を支配するというランダムサイトモデル ${ }^{2122)}$, (2) 逆に $\mu$ は一定で $n$ の変化が $\sigma$ の変化を支配するという弱電解質モデ ル2223), および著者らが主張しているように，(3） $n$ も $\mu$ も変 化し，その結果として $\sigma$ が変化するという拡散路モデル316)24) で ある。

（1）のランダムサイトモデルでは，伝導に寄与する可能性の ある陽イオンは，そのすべてが荷電担体となり，一方，活性化エ ネルギーがサイトことに異なるために分布をもち，これを反映し て移動度は組成の変化に応じて変化する。一般に, 組成の変化に よるイオン濃度の変化は小さいので, 組成変化による伝導度の変 化は主として移動度の変化によって支配されることになる ${ }^{2122) 。 ~}$

（2）の弱電解質モデルでは, 伝導に寄与する可能性のあるイ オンもすべては荷電担体として作用せず，弱電解質におけるのと 同様，一部だけがイオンに解離し，この解離したイオンだけが伝 導に寄与する。一方，移動度は組成によらず一定であり，したが って組成の変化による伝導度の変化は, 解離したイオンの濃度 (荷電担体の濃度)に支配されることになる22)23)。

（3）の拡散路モデルは，ガラス中には酸素酸イオンと部分的 共有結合で強く結ばれていて動きにくい $\mathrm{Ag}^{+}$イオンと, $\mathrm{I}^{-}$イオ ンに取四をれていて動きやすい $\mathrm{Ag}^{+}$イオンと 2 種類あって，こ

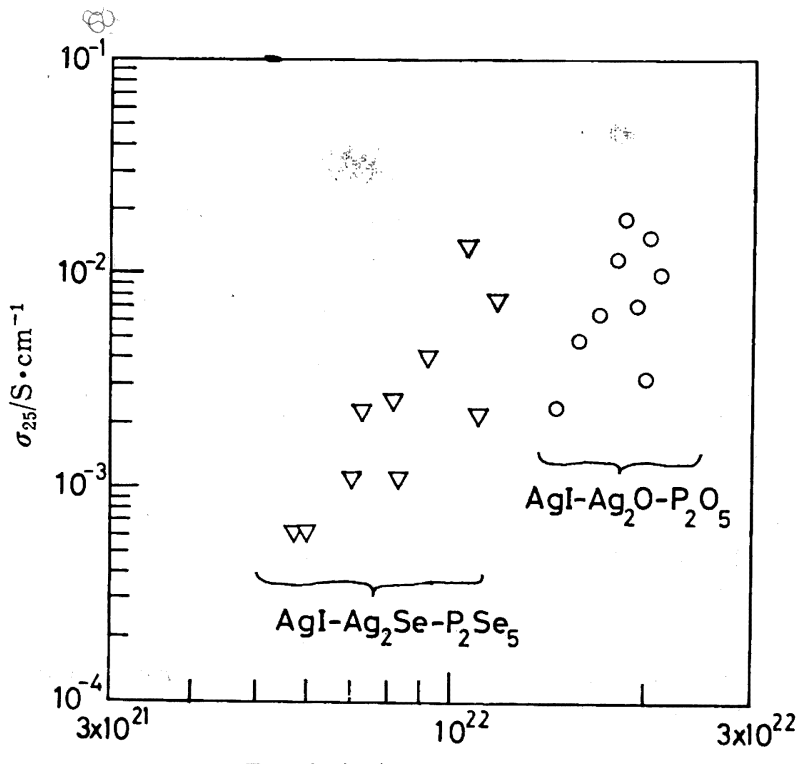

Total $\mathrm{Ag}^{+}$ions $/ \mathrm{cm}^{3}$ in glass

Fig. 8 Relation between the conductivity at $25^{\circ} \mathrm{C}$ and the total concentration of $\mathrm{Ag}^{+}$ions in the $\mathrm{AgI}-\mathrm{Ag}_{2} \mathrm{Ch}-\mathrm{P}_{2} \mathrm{Ch}_{5}$ glasses $(\mathrm{Ch}=\mathrm{O}, \mathrm{Se})$

$\mathrm{O}: \mathrm{AgI}-\mathrm{Ag}_{2} \mathrm{O}-\mathrm{P}_{2} \mathrm{O}_{5}$ glasses

$\nabla: \mathrm{AgI}-\mathrm{Ag}_{2} \mathrm{Se}-\mathrm{P}_{2} \mathrm{Se}_{5}$ glasses

21) K. E. D. Wapenaar, J. Schoonman, J. Electrochem. Soc., 126, 667(1979).

22) A. M. Glass, J. Appl. Phys., 51, 3756(1980).

23) D. Ravaine, J. L. Souquet, Phys. Chem. Glasses, 18, 271(1977).

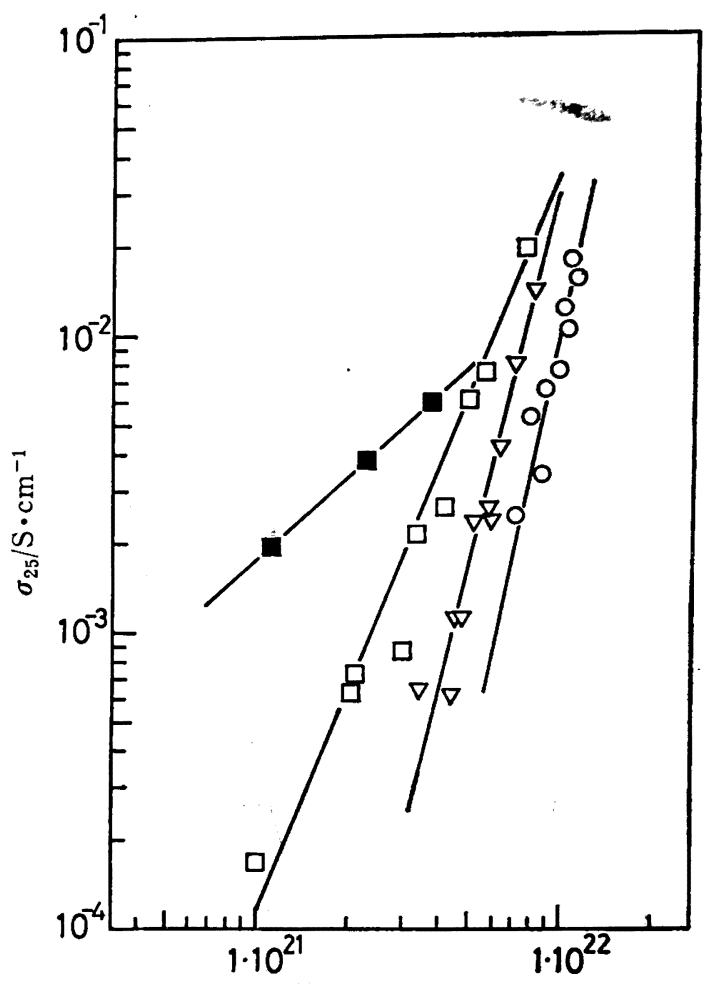

$\mathrm{Ag}^{+}$ions $/ \mathrm{cm}^{3}$ from $\mathrm{AgI}$ in glass

Fig. 9 Relation between the conductivity at $25^{\circ} \mathrm{C}$ and the partial concentration of $\mathrm{Ag}^{+}$ions brought to the $\mathrm{AgI}-\mathrm{Ag}_{2} \mathrm{Ch}-\mathrm{P}_{2} \mathrm{Ch}_{5}$ glasses from the AgI component $(\mathrm{Ch}=\mathrm{O}, \mathrm{S}, \mathrm{Se})$
$\mathrm{O}: \mathrm{AgI}-\mathrm{Ag}_{2} \mathrm{O}-\mathrm{P}_{2} \mathrm{O}_{5}$ glasses
$\square: \mathrm{AgI}-\mathrm{Ag}_{2} \mathrm{~S}-\mathrm{P}_{2} \mathrm{~S}_{5}$ glasses $\left(\mathrm{Ag}_{2} \mathrm{~S} / \mathrm{P}_{2} \mathrm{~S}_{5} \neq 2\right)$
: $\mathrm{AgI}-\mathrm{Ag}_{2} \mathrm{~S}-\mathrm{P}_{2} \mathrm{~S}_{5}$ glasses $\left(\mathrm{Ag}_{2} \mathrm{~S} / \mathrm{P}_{2} \mathrm{~S}_{5}=2\right)$
$\nabla: \mathrm{AgI}-\mathrm{Ag}_{2} \mathrm{Se}-\mathrm{P}_{2} \mathrm{Se}_{5}$ glasses

の動きやすい $\mathrm{Ag}^{+}$イオンが， $\mathrm{I}^{-}$イオンでできた道筋（拡散路） を移動するというものである。したがって, $\mathrm{Ag}^{+}$イオンの一部が 伝導に寄与し, 拡散路の長さによって移動度も变化することにな る $^{3) 6) 241}$ 。

この三つの説のいずれがもっとも妥当であるか，また結論の得 られていないのが現状である22)25)。ここでとりあげた $\mathrm{AgI}-\mathrm{Ag}_{2}$. $\mathrm{Ch}-\mathrm{P}_{2} \mathrm{Ch}_{5}$ 系について, このような問題をつぎに検討する。

図 8 に伝導度 $\left(25^{\circ} \mathrm{C}\right)$ と銀イオン濃度との関係を示す。この四 の横軸は，ガラス中のすべての銀イオンの濃度で表示してある。 プロットが錯綜して図が煩雑になるのを避げるために、ここには $\mathrm{Ch}=\mathrm{O}$ と $\mathrm{Se}$ の系のガラスのデータだけを示してある。図から， 全銀イオン浱度が増加すると伝導度が增加する傾向はみられる が，全体としてかなりばらつきが大きく，相関性を論じることは 困難である。

図 9 には, 図 8 と同じ伝導度を縦軸に, 横軸には AgI 成分か ら生じた $\mathrm{Ag}^{+}$イオン濃度でプロットした。この図には $\mathrm{Ch}=\mathrm{O}$, $\mathrm{S}$, Se の-べてのがラスの結果を示したが, 四から明らかなよう に，図8ではばらついていたプロットが，行系ともそれぞれかな りよい直線に乘っている $\left(\mathrm{Ch}=\mathrm{S}\right.$ の埸合, $\mathrm{Ag}_{2} \mathrm{~S} / \mathrm{P}_{2} \mathrm{~S}_{3}$ のモル此=

24) T. Minami, J. Non-Cryst. Solids, 73, 273(1985).

25) D. P. Button, R. T. Tandon, H. L. Tuller, D. R. Uhlmann, J. Non-Cryst. Solids, 42, 297(1980). 


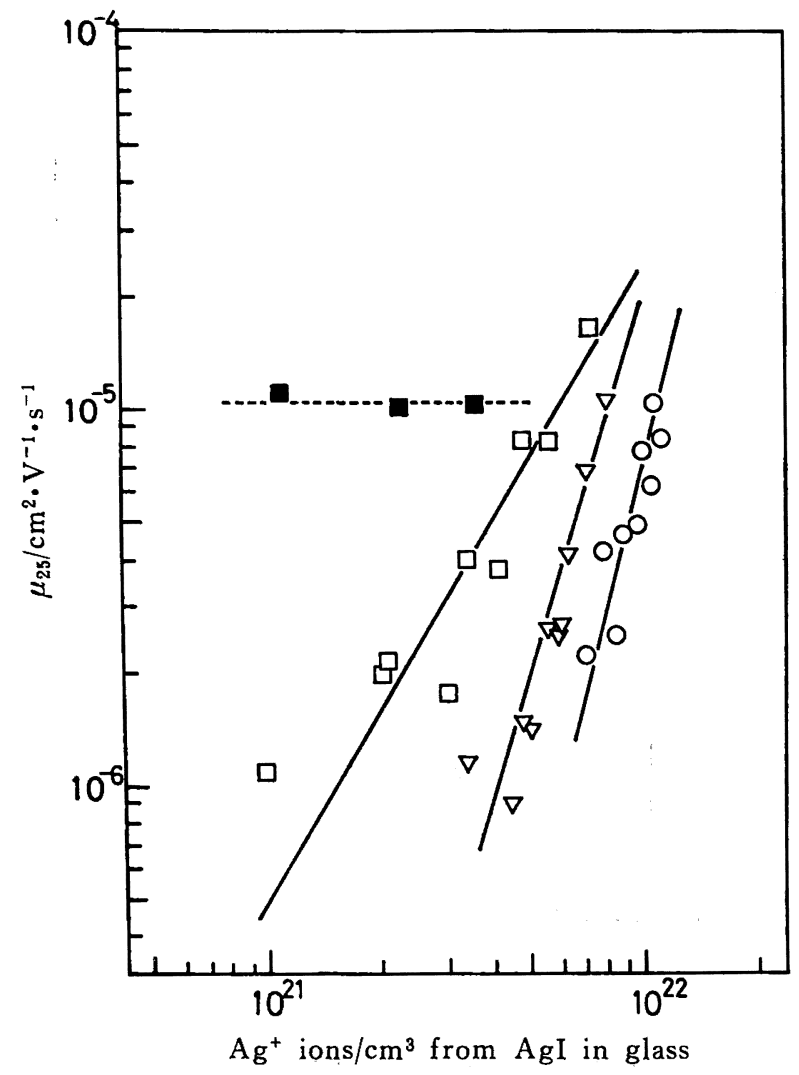

Fig. 10 Relation between the estimated mobility at $25^{\circ} \mathrm{C}$ and concentration of $\mathrm{Ag}^{+}$ions in the $\mathrm{AgI}-\mathrm{Ag}_{2} \mathrm{Ch}-\mathrm{P}_{2} \mathrm{Ch}_{5}$ glasses $(\mathrm{Ch}=\mathrm{O}, \mathrm{S}, \mathrm{Se})$

For the estimation of mobility the $\mathrm{Ag}^{+}$ion concentration in Fig. 9 was used as the concentration of charge carriers.

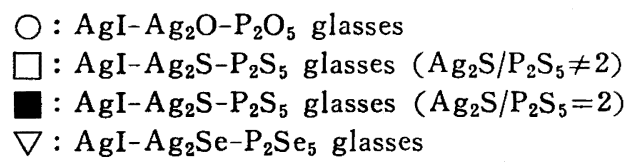

2 のガラスだけが異なる挙動を示しているが，このことは後で述 ベる)。図9の結果は, これらのガラスの中では, すべての銀イオ ンが伝導に寄与しているのではなく, 一部が寄与していることを 示するのと解釈することができる。

以上の結果は, ランダムサイトモデルが成立しないことを意味 する。

電気公導度 $\sigma$ は ( 6 )式に示したよらに, $n, e, \mu 3$ 者の積で表 される。いま $n$ として，図 9 に示した $\mathrm{Ag}^{+}$イオンの濃度を採用 すると，(1)式から $\mu$ を算出することができる。こうして算出し た $\mu$ の組成依存性を四 10 に示す。この場合, 組成依存性を見る
ためには横軸としていろいろの表示法が可能であるが, 種々試み た結果, 図 9 と同じく, $\mathrm{AgI}$ 成分から生じた $\mathrm{Ag}^{+}$イオン濃度を 用いて図示した。この図の横軸はもちろん組成が変わ施いるこ とを意味するが, 組成が変わったとき, 明らかに移動度も変化し ている。

このことは弱電解質モデルも成立しないことを意味する。ただ し, $\mathrm{Ch}=\mathrm{S}$ のとき, $\mathrm{Ag}_{2} \mathrm{~S} / \mathrm{P}_{2} \mathrm{~S}_{5}$ のモル比=2 の組成のガラスは, 図 10 の黑い四角印で示されるように, 組成が変わっても移動度 はほとんど変化していない。このことは, ある特定の組成の領域 では弱電解質モデルが成立している可能性を示しており,さらに 今後の検討を要する。

しかしながら, 全体としてみれば, 陽イオンのすべてが伝導に 寄与しているのではなく，一部が伝導に寄与しており，また組成 が変わると移動度も変化していて，さきにあげた（ 3 )の拡散路モ デルの考え方が妥当であることを示していると解釈することがで きる。

最近, この種の超イオン伝導ガラスの長範囲 X 線吸収 (EXA FS) ${ }^{26)}$ やラマンスペクトル27), さらには熱起電能の測定 ${ }^{28)}$ な゙ から, $\mathrm{Ag}^{+}$イオンには 2 種類あるという集験結果も示されてお り，（3）の説が有力になりつつある。ただ図 10 の黑い四角印の よらな現象もあり，今後の検討がな怙必要である。また図 8〜10 においては, $\mathrm{AgI}-\mathrm{Ag}_{2} \mathrm{Ch}-\mathrm{P}_{2} \mathrm{Ch}_{5}$ 三成分系について考察されてい て, $\mathrm{AgI}$ を含まない $\mathrm{Ag}_{2} \mathrm{~S}-\mathrm{P}_{2} \mathrm{~S}_{5}$ 系は対象外になっている。しかし ながら，図6からもわかるように，AgI を含まない系でも，ある 程度の伝導度が得られている。このことは，ある伝導度の値（た とえば $10^{-5} \mathrm{~S} \cdot \mathrm{cm}^{-1}$ 程度) よりも低い伝導度のガラスでは, $\mathrm{Ag}_{2} \mathrm{O}$ として導入された $\mathrm{Ag}^{+}$イオンも伝導に関与していることを示し ている (実際, $\mathrm{AgI}$ を含まない多くのガラ゙スに $\mathrm{Ag}_{2} \mathrm{O}$ や $\mathrm{Na}_{2} \mathrm{O}$ が導入されて，低いながらもある程度の伝導度が生じるのはこの ためである)。伝導機粠のより精確な解明のために，伝導度とは 独立にキャリヤー濃度を算出することが非常に重要であると考え られる。現在, そのような湘定を試みており, その結果をふまえ て，これらのな找された問題については，機会を改めて報告し たい。

本研究の一部は文部省科学研究費の援助を受けた。記して謝意 を表する。

26) G. Dalba, A. Fontana, P. Fornasini, G. Marotto, M. R. Masullo, F. Rocca, Solid State Ionics, 9/10, 579 (1983).

27) J. P. Malugani, R. Mercier, ibid., 13, 293(1984).

28) A. Schiraldi, E. Pezzati, P. Baldini, J. Phys. Chem., 89, 1528(1985). 


\title{
Special Articles on \\ Electrically Conducting Materials and Their Applications
}

\author{
Preparation and Conduction Mechanism of Superionic Conducting \\ Glasses in the Systems $\mathrm{Agl}-\mathrm{Ag}_{2} \mathrm{Ch}_{-} \mathrm{P}_{2} \mathrm{Ch}_{5}(\mathrm{Ch}=\mathrm{O}, \mathrm{S}, \mathrm{Se})$
}

Tsutomu Minami* and Takumi Shimizu

Department of Applied Chemistry, University of Osaka Prefecture;

Sakai-shi 591 Japan

Superionic conducting glasses in the systems $\mathrm{AgI}-\mathrm{Ag}_{2} \mathrm{Ch}-\mathrm{P}_{2} \mathrm{Ch}_{5}(\mathrm{Ch}=\mathrm{O}, \mathrm{S}, \mathrm{Se})$ were prepared and their properties such as glass transition temperatures, ionic conductivities, electronic conductivities and ion transport numbers were measured. The effect of the replacement of anions, $\mathrm{O}, \mathrm{S}$ and $\mathrm{Se}$, on these properties and the conduction mechanism were discussed.

The glass-forming region was the widest in the sulfide system ; in oxide and selenide systems the region was smaller and similar each other in the area in the composition triangles. The glass transition temperatures ranged from 50 to $230^{\circ} \mathrm{C}$ and increased in the order of oxide, sulfide and selenide glasses, provided that the glasses contained the same amounts of AgI, $\mathrm{Ag}_{2} \mathrm{Ch}$ and $\mathrm{P}_{2} \mathrm{Ch}_{5}$. The composition dependence of glass transition temperatures suggested the presence of partial covalency between $\mathrm{Ag}^{+}$and nonbridging anions $\mathrm{Ch}^{-}$. The conducitivity as high as $10^{-2} \mathrm{~S} \cdot \mathrm{cm}^{-1}$ at room temperatare was obtained in each system. The measurement of ion transport numbers revealed that all the glasses obtained were nearly $100 \% \mathrm{Ag}^{+}$ion conductors. The electron conductivity was less by 5 to 7 orders of magnitude than the total conductivity. The diffusion path model was concluded to be a more reasonable mechanism of conduction than the random site or the weak electrolyte model. 